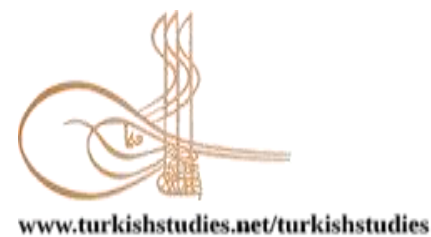

Turkish Studies

\title{
Hentbol Sporcularının, Takım Antrenörlerinin Sahip Olduğu Karizmatik Liderlik Algılarının Takım Bütünlüğüne Etkisinin İncelenmesi
}

\author{
Analysis of the Effect of the Charismatic Leadership Perception of Male 1st League Handball \\ Athletes About Team Coaches on Team Unity in Terms of Certain Variables
}

\author{
Ahmet Yılmaz Albayrak* - Yeşim Bayrakdaroğlu** - T. Osman Mutlu***
}

\begin{abstract}
This study was designed to analyze the effect of charismatic leadership perception of the male handball athletes, who play in the 1st league of Turkish Handball Federation in 2018-2019 season, about their team coaches on tem unity in terms of certain variables. 112 athletes taking part in 13 teams competing in 2018-2019 male 1st league handball season form the sample group. In order to collect data, Charismatic Leadership and Group Unity Scales were used. In the analysis of data; descriptive statistics such as mean value, standard deviation, frequency/percentage, normal distribution test (Kolmogorov-Smirnov test) were used along with t-test (Mann-Withney U test) for dual comparisons and variance analysis (Kruskal Wallis-H test) for multiple comparisons to test the hypotheses of the study. As a result of analysis, a statistically significant difference was found between effective speech skill $(\mathrm{U}=949.500, \mathrm{p}<0.05)$ and social attractiveness of the group $(U=834.000, p<0.05)$ subscales in terms of educational status variable of the athletes. Also a statistically significant difference was found between personalized interest $\chi 2(s d=3, n=112)=8.109, p<0.05)$ and group unity in task $\left.\chi^{2}(\mathrm{sd}=3, \mathrm{n}=112)=8.686, \mathrm{p}<0.05\right)$ subscales in terms of age variable. A statistically significant difference was found between extraordinary appearance $\left.\chi^{2}(\mathrm{sd}=3, \mathrm{n}=112)=7.812, \mathrm{p}<0.05\right)$, adopting values $\left.\chi^{2}(\mathrm{sd}=3, \mathrm{n}=112)=9.551, \mathrm{p}<0.05\right)$, social unity of the group $\chi^{2}(\mathrm{sd}=3, \mathrm{n}=112)=8.319$, $\mathrm{p}<0.05)$ and group unity in task $\chi 2(\mathrm{sd}=3, \mathrm{n}=112)=13.177, \mathrm{p}<0.05)$ subscales in terms of sports year variable. No statistically significant differences were found between other subscales.
\end{abstract}

Structured abstract: Introduction: Leadership is the ability of a leader to influence the people who follow him/her and to bring them together and guide them in line with specific objectives in order to achieve a goal or purpose (Chaudhry and Javed, 2012). Charismatic leadership, which is one of the modern approaches to

\footnotetext{
* Dr. Öğr. Üyesi, Gümüşhane Üniversitesi, Beden Eğitimi ve Spor Yüksekokulu, Spor Yöneticiliği Asst. Prof. Dr., Gumushane University

Checked by plagiarism software

Published/Yayın: 31 August/Ağustos 2020

CC BY-NC 4.0 
the field of leadership, is the process of giving meaning to the success of the organization by instilling moral purpose and commitment into the organization and actions for the organization's performance (House and Howell, 1992: 82).

Group cohesion (environment), which is defined by an organization, group or team acting together and pursuing instrumental goals (Carron et al., 2002: 119-120), is characterized by a harmonious group or "commitment" by group members (Mudrack, 1989:39). It is seen that charismatic leaders ensure team cohesion (environment) by demonstrating critical behaviors such as motivating team members, establishing trust, developing trust and commitment, and acting as a role (Katzenbach et al., 1993:111).

Methodology: In the study, 112 players who competed in the Turkey Handball Federation 20182019 Men's Premier League Handball Season from 13 different teams created the sample group. In the data collection, the charismatic leadership scale, which was created in the form of a four-point Likert and gathered under ten dimensions by Veli Onur Celik in 2011, and the Group Environment Questionnaire developed by Carron, Brawley and Widmeyer (1985) were used.

Data Analysis: In order to test the hypotheses of the research, a t-test (Mann-Whitney U test) in paired comparisons and variance analysis (Kruskal Wallis-H test) in multiple comparisons were used besides descriptive statistics such as mean, standard deviation, frequency/percentage, normal distribution test, (Kolmogorov-Smirnov test). After the variance analysis test, the Bonferroni correction method was used to prevent type I and type II errors that may result from paired comparisons performed in order to determine in which groups the significant difference was found. The significance level (0.05) for age and sports age variables was divided into the number of Mann-Whitney $U$ test (6) and the significance level was determined as 0.008 .

Results: As a result of analysis, a statistically significant difference was found between effective speech skill $(U=949.500, p<0.05)$ and social attractiveness of the group $(U=834.000, p<0.05)$ subscales in terms of educational status variable of the athletes. Also a statistically significant difference was found between personalized interest $\left.\chi^{2}(\mathrm{sd}=3, \mathrm{n}=112)=8.109, \mathrm{p}<0.05\right)$ and group unity in task $\chi 2(\mathrm{sd}=3, \mathrm{n}=112)=$ 8.686, $\mathrm{p}<0.05)$ subscales in terms of age variable. A statistically significant difference was found between extraordinary appearance $\left.\chi^{2}(\mathrm{sd}=3, \mathrm{n}=112)=7.812, \mathrm{p}<0.05\right)$, adopting values $\chi^{2}(\mathrm{sd}=3, \mathrm{n}=112)=9.551$, $\mathrm{p}<0.05)$, social unity of the group $\chi 2(\mathrm{sd}=3, \mathrm{n}=112)=8.319, \mathrm{p}<0.05)$ and group unity in $\operatorname{task} \chi 2(\mathrm{sd}=3, \mathrm{n}=112)$ $=13.177, \mathrm{p}<0.05)$ subscales in terms of sports year variable. No statistically significant differences were found between other subscales.

Keywords: Leadership, Charismatic Leadership, Team Unity, Male $1^{\text {st }}$ League Handball Athletes, Charismatic Leadership Perception

Öz: Bu çalışma Türkiye Hentbol Federasyonu 2018-2019 erkek 1. Lig Hentbol sezonunda hentbol oynayan sporcuların, takım antrenörlerinin karizmatik liderlik algılarının takım bütünlügüne etkisinin bazı değişkenler açısından incelenmesi amacıyla hazırlanmıştır. 2018-2019 erkek 1. Lig hentbol sezonunda mücadele eden 13 takımda görev yapan 112 sporcu örneklem grubunu oluşturmuştur. Verilerin toplanmasında kullanılmak üzere Karizmatik Liderlik ve Grup Bütünlüğü Ölçekleri kullanılmıştır. Araştırmanın hipotezlerini test etmek amacıyla verilerinin analizinde, ortalama, standart sapma, frekans/yüzde, normal dağılım testi, (KolmogorovSmirnov test), gibi betimsel istatistiklerin yanında, ikili karşılaştırmalarda t-testi (Mann-Withney U test), çoklu karşılaştırmalarda varyans analizi (Kruskal Wallis-H test) yapılmıştır. Analizler sonucunda; sporcuların eğitim durumu değişkenine göre etkili konuşma becerisi ( $U=949.500, p<0.05)$ ve grubun sosyal çekiciliği $(\mathrm{U}=834.000, \mathrm{p}<0.05)$, yaş değişkeni ile kişiselleştirilmiş ilgi $\chi 2(\mathrm{sd}=3, \mathrm{n}=112)=8.109, \mathrm{p}<0.05)$ ve grubun görevde bütünleşmesi $\chi 2(\mathrm{sd}=3, \mathrm{n}=112)=8.686, \mathrm{p}<0.05$, spor yaşı değişkeni ile sıradış1 görünüş $\chi 2(\mathrm{sd}=3$, $\mathrm{n}=112)=7.812, \mathrm{p}<0.05)$, değerlerine sahip ç1kma $\chi 2(\mathrm{sd}=3, \mathrm{n}=112)=9.551, \mathrm{p}<0.05)$, grubun sosyal bütünleşmesi $\left.\chi^{2}(\mathrm{sd}=3, \mathrm{n}=112)=8.319, \mathrm{p}<0.05\right)$ ve grubun görevde bütünleşmesi $\chi 2(\mathrm{sd}=3, \mathrm{n}=112)=$ 13.177, $\mathrm{p}<0.05$ ) alt boyutları arasında, istatistiksel olarak anlamlı farklılık tespit edilmiş, diğger alt boyutlar arasında, istatistiksel olarak anlamlı farklılık tespit edilmemiştir.

Anahtar Kelimeler: Liderlik, Karizmatik Liderlik, Takım Bütünlüğü, Erkek 1.Lig Hentbol Sporcuları, Karizmatik Liderlik Algısı 


\section{Giriş}

Liderlik, eski çağlardan beri insanlarda merak uyandıran bir konu olmuştur. Liderlerin izleyicileri ne kadar etkiledikleri tam olarak anlaşılamamasına rağmen tarihte askeri, siyasi, dini ve toplumsal liderlerin hikâyeleri mevcuttur (Yukl, 2018: 1). Liderlik aynı zamanda Machiavelli'nin "Prens" ve Platon'un "Devlet", adlı eserlerinde ana konu olarak işlendiği görülmektedir (Saylı \& Baytok, 2014: 6).

Liderlik bir hedefin veya amacın başarılabilmesi için liderin kendisini takıp eden insanları etkileyebilmesi ve onları bir araya getirerek belli amaçlar doğrultusunda yönlendirme becerisidir (Chaudhry \& Javed, 2012). Buna rağmen, bir kişinin hangi özelliklere, yetenek ve şartlara bağlı olarak lider olacağına veya bir liderin ne zaman ön planda olacağ 1 sorusunun cevabını kesin yanıtlarla vermek olanaksızdır. (Güney, 2014: 18). Son yıllarda iş ve çalışma şartlarının değişmesi ile birlikte yöneticilerin, çalışanların gereksinimleri ve beklentilerinin farklılaşması sonucu liderlik alanında da yeni yaklaşımlar gündeme gelmiştir ve bu yeni yaklaşımlardan biri de "Karizmatik Liderlik" tir (Çelik, 2015:105).

"Karizmatik Liderlik" kelime öbeğinin temelini oluşturan Karizma kelimesi sosyolojide ve yönetim bilimi alanlarında ilk kez karşımıza Max Weber ile çıkmıştır. Max Weber"in "karizmatik yetki" kavramını kullanması ile literatüre girmiştir (Deliveli, 2010). Weber, bireyin kıymetli gördükleri ve nitelikleriyle liderdir, demiştir. Karizmatik otoritenin hakim olduğu liderliği ise Weber, nadir rastlanan bir bireye inanma ve onun yolundan gitme olarak tanımlamakta olup karizmatik otoritenin, liderin bireysel özelliklerine dayandığına değinmektedir (Hoy \& Miksel, 2010).

Karizmatik liderliğin özellikleri McGill Üniversitesi'nden Conger ve Kanungo tarafından yapılan araştırmalarla şu şekilde araştırılmışıı. Karizmatik liderler, toplumun benimsediği örf ve adetlere, inanışlara uymayan ve özgüveni yüksek kişilerdir. Karizmatik bir lider, mevcut durumu korumaz; gerektiğinde köklü değiş̧iklikler yapabilen kişilerdir (Ertan-Kantos, 2011: 141). Bireyin sahip olduğu karizma, etrafındakileri etkilemede önemli rol oynamaktadır. Bu davranış tarzında lider karizma yaratan özellikleri ile, başkalarını kendi istediği yönde davranmaya yönlendirebilmektedir. Karizmatik lider izleyicilerini üstün performans sergilemeleri konusunda teşvik eder (Koçel 1999: 424).

Vizyoner ve ilham verici yetenek, sözsüz iletişim, ideolojik değerlere hitap etme gibi özelliklere sahip karizmatik liderler, takipçilerin duygusal ve motivasyonel uyarılmaları; liderin dile getirdiği misyonla ilgili olarak takipçi değerlerinin artırılması üzerinde durur. Karizmatik lider, takipçilerin bilişlerini veya görev ortamını etkilemek yerine takipçilerin özsaygı ve lidere olan güvenle; örgütün performansı için örgüte ve eylemlere ahlaki amaç ve bağl1lık aşılayarak örgütün başarısına anlam kazandırdığı görülmektedir (House \& Howell, 1992: 82).

İnsanların bir amaç ve hedef etrafinda toplandığı, sportif etkinlik ve spor hizmeti beklentilerini önemli ölçüde karşıladığı örgütler olarak spor kulüpleri (Demirel vd., 2007: 77), sergiledikleri performanslar ile birbirlerine bağımlı olmayan sporcu üyelerden ya da başarıya ulaşmak için bütünlük içinde koordineli bir şekilde çaba harcayan sporculardan oluşmaktadır (Çelik, 2011: 29).

Bir örgütün, grubun ya da takımın birlikte hareket etme ve araçsal hedeflerinin peşinde ve / veya üye hedeflerinin ihtiyaçlarını karşılamada birleşik kalma eğiliminde olması, genel olarak takım bağlılılı̆g olarak adlandırılan takım uyumu ve takım başarısı ile ilgili dinamik bir süreç olduğu varsayılan grup bütünlüğü (sargınlığı) kavramı 1940 ve 1950'li yıllarda ortaya çıkmıştır. Bu süreç üyelerin grubun görevine olan kişisel katılımı hakkındaki duyguları; grupla kişisel sosyal etkileşimleri hakkındaki duyguları; görev ve hedefleri etrafında bir bütün olarak grubun benzerliği ve birliği ile ilgili algıları; ve grubun bir sosyal birim olarak benzerliği ve birliği hakkındaki algısı 
olmak üzere dört temel yapının bir sonucu olduğu düşünülen kavramsal bir modele dayandırılmıştır (Carron vd., 2002: 119-120; Carron vd., 1985:248).

Grup bütünlüğü (sargınlığı) grup üyeleri tarafindan uyumlu bir grup veya "bağl1lık" ile karakterize edilmektedir. Bütünlük grup üyeleri tarafindan bireysel farklılık ve güdüleri aşmak için ortaya çıkan kuvvetler olarak tanımlanmaktadır. Üyeler üzerinde grup halinde kalmak; başka bir deyişle bağl1lık, bir gruba üyeliğin üyeleri için grubun cazibesidir. 'Güçlü bağlar' ile yansıtılan grub bütünlüğü (sargınlığı) kavramı gruba cazibe veya ayrılmaya karşı direnç olarak kabul edilmektedir (Mudrack, 1989:39). Daha sonra çağdaş grup bütünlüğü (sargınlığı) tanımları yapılmış olsa da sargınlık genel olarak, üyelerin birbirlerini ve grubu çekici bulma derecesi olarak kavramsallaştırılmıştır (Öcel \& Aydın, 2006).

Takım liderliği, lider olarak, "öncelikli olarak takım hedeflerini tanımlamaktan ve bu görevleri yerine getirmek için takımı geliştirmek ve yapılandırmaktan sorumlu" bir süreçtir. (Zaccaro vd., 2001:452). Lider, etkili takım performansı için ekip üyelerinin bireysel eylemlerini başarıyla entegre etmek, takımın karmaşı ve dinamik ortamlarda performans gösterebilmek, grup üyelerinin grubun bir parçası hissetme ve grupta kalma arzusu kılmak gibi grup davranışının en güçlü tahmincisi olarak görülmektedir. Liderlik tarzı ve bütünlük (sargınlık) takım çalışması kalitesinin önemli yönlerinden biridir ve ekip üyelerinin ekipte kalma, birbirlerine çalışma isteklerini etkileyen faktörlerdir (Wang vd., 2005: 174-175).

Karizmatik liderlerin değerlerinin ve hedeflerinin takipçiler tarafından güçlü bir şekilde içselleştirilmesi, bu değerlere ahlaki bağlılığı ve takipçilerin kollektif uğruna kendi çıkarlarını aşma eğilimi göstermeleri (Hause vd., 1990:216), ayrıca ekip üyelerini hevesli kılmak, güven yaratmak, güven ve bağl1lık geliştirmek ve rol olarak hareket etmek gibi kritik davranışları ortaya koyarak takım bütünlüğünü (sargınlığı) sağladıkları görülmektedir (Katzenbach vd., 1993:111).

\section{Materyal Metod}

Çalı̧̧mada Türkiye Hentbol Federasyonu 2018-2019 erkek 1. Lig hentbol sezonunda mücadele eden 13 takımda görev yapan 112 sporcu örneklem grubunu oluşturmuştur. Verilerin toplanmasında Veli Onur Çelik'in 2011 yılında geliştirmiş olduğu dörtlü Likert şeklinde oluşturulmuş on boyut altında toplanmış karizmatik liderlik ölçeği kullanılmıştır. Ölçeğe ilişkin KMO değeri 0,775, Cronbach Alpha testi değeri ise ,955 olduğu tespit edilmiştir. Katılımcıların grup/takım bütünlüğünün (sargınlığının) ölçülmesinde, Carron, Brawler ve Widmeyer (1985) tarafından geliştirilen Grup Bütünlüğü (Sargınlığı) Ölçeği (Group Environment Questionnaire) kullanılmıştır. Grup Bütünlüğü (Sargınlığı) Envanteri, öngörülen dört sargınlık alt boyutunu içeren toplam 18 maddeden oluşmaktadır. Ölçeğin Türk sporcuları için uyarlanması Öcel (2002) tarafından gerçekleştirilmiştir. Çalışma kapsamında Cronbach Alpha değeri karizmatik liderlik ölçeği için ,922, takım bütünlüğü (sargınlığı) ölçeği için ise ,771 olarak tespit edilmiştir.

\section{Verilerin Analizi:}

Araştırmanın hipotezlerini test etmek amaciyla verilerinin analizinde, ortalama, standart sapma, frekans/yüzde, normal dağılım testi, (Kolmogorov-Smirnov test), gibi betimsel istatistiklerin yanında, ikili karşılaştırmalarda t-testi (Mann-WithneyU test), çoklu karşılaştırmalarda varyans analizi (Kruskal Wallis-H test) kullanılmıştır. Varyans analizi testinten sonra anlamlı farklılığın hangi gruplarda olduğunu belirlemek için yapılan ikili karşılaştırmalardan kaynaklanabilecek tip I ve tip II hataları önlemek için bonferroni düzeltme yöntemi kullanılmıştır. Yaş ve spor yaş1 değişkenleri için anlamlılık düzeyi (0.05) yapılan Mann-Withney U testi miktarına (6) bölünmüş ve anlamlılık düzeyi 0.008 olarak belirlenmiştir. 


\section{Bulgular ve Yorum}

Araştırma kapsamında elde edilen veriler üzerinde yapılan analizlere ilişkin sonuçlar bu bölümde raporlanmıştır. Araştırmanın demografik değişkenlerine ait analiz sonuçları tablo 1'de sunulmuştur.

Tablo 1. Sporcuların demografik özelliklerine göre istatistiksel dağılımları

\begin{tabular}{|c|c|c|c|c|c|}
\hline Cinsiyet & $\mathbf{N}$ & $\%$ & Branş & $\mathbf{N}$ & $\%$ \\
\hline 1. Erkek & 112 & 100.0 & 1.hentbol & 112 & 100.0 \\
\hline Toplam & 112 & 100.0 & Toplam & 112 & 100.0 \\
\hline Mücadele Edilen Lig & & & Eğitim Durumu & & \\
\hline 1. Hentbol 1. Lig & 112 & 100.0 & 1. Lise ve alt1 & 31 & 27.7 \\
\hline \multirow[t]{2}{*}{ Toplam } & 112 & 100.0 & 2. Üniversite ve üstü & 81 & 72.3 \\
\hline & & & Toplam & 112 & 100.0 \\
\hline Yaş & & & Spor Yaşı & & \\
\hline 1. 18 yaş ve altı & 16 & 14.3 & 1. 5 yll ve alt1 & 22 & 19.6 \\
\hline 2. $19-22$ yaş arası & 50 & 44.6 & 2. 6-10 y1l aras1 & 47 & 42.0 \\
\hline 3. $23-26$ yaş arası & 24 & 21.4 & 3. $11-15$ y1l aras1 & 23 & 20.5 \\
\hline 4. 27 yaş ve üstü & 22 & 19.6 & 4. 16 yıl ve üstü & 20 & 17.9 \\
\hline Toplam & 112 & 100.0 & Toplam & 112 & 100.0 \\
\hline \multicolumn{6}{|l|}{ MAÇS } \\
\hline 1. 2 yil ve alt1 & 76 & 67.9 & & & \\
\hline 2. 3 y1l ve üstü & 36 & 32.1 & & & \\
\hline Toplam & 112 & 100.0 & & & \\
\hline
\end{tabular}

\section{(MAÇS = Mevcut Antrenörle Çalışma Süresi)}

Tablo 1'i incelediğimizde, katılımcıların 1. Hentbol liginde mücadele eden erkek sporculardan oluş̧uğu görülmektedir. Sporcuların eğitim durumu değişkenine ilişkin sonuçlara bakıldığında 31 sporcunun lise ve altı öğretim programlarından mezun olduğu, 81 sporcunun ise üniversite ve üstü öğretim programlarından mezun olduğunu göstermektedir. Yaş değişkenine göre dağılım, 16 sporcunun 18 yaş ve altı, 50 sporcunun 19-22 yaş, 24 sporcunun 23-26 yaş ve 22 sporcunun ise 27 yaş ve üstü şeklinde gerçekleşmiştir. Spor yaşı değişkenine göre ise, 22 sporcunun 5 y1l ve alt1, 47 sporcunun 6-10 y1l aras1 23 sporcunun 11-15 y1l ve 20 sporcunun 16 y1l ve üstü bir spor tecrübesine sahip olduğunu göstermektedir. 76 Sporcu \% 67,9'luk bir oranla mevcut antrenörü ile 2 yıl ve altı süre çalışmışken, 36 sporcu \% 32,1 oranı ile mevcut antrenörü ile 3 yıl veya daha uzun süre çalışmıştır.

Eğitim durumu değişkeni ile bağımlı değişkenler arasındaki anlamlı farklılığın tespitine yönelik t-testi sonuçları tablo 2'de sunulmuştur. 
Tablo 2. Sporcuların Karizmatik Liderlik Ve Grup Sargınlığı Algı Düzeylerinin Eğitim Durumu Değişkenine Göre Karşılaştırılması

\begin{tabular}{|c|c|c|c|c|c|c|}
\hline Bağımlı Değişkenler & Eğitim Durumu & $\mathbf{N}$ & Sira ort. & Sura top. & $\mathbf{U}$ & $\mathbf{p}$ \\
\hline \multirow{2}{*}{ Kişiselleştirilmiş İlgi } & 1. Lise ve altı & 31 & 57.03 & 1768.00 & \multirow{2}{*}{1239.000} & \multirow{2}{*}{.914} \\
\hline & 2. Üniversite ve üstü & 81 & 56.30 & 4560.00 & & \\
\hline \multirow{2}{*}{ Güven } & 1. Lise ve alt 1 & 31 & 62.44 & 1935.50 & \multirow{2}{*}{1071.500} & \multirow{2}{*}{.229} \\
\hline & 2. Üniversite ve üstü & 81 & 54.23 & 4392.50 & & \\
\hline \multirow{2}{*}{ Antipatik Algı } & 1. Lise ve alt 1 & 31 & 54.56 & 1691.50 & \multirow{2}{*}{1195.500} & \multirow{2}{*}{.695} \\
\hline & 2. Üniversite ve üstü & 81 & 57.24 & 4636.50 & & \\
\hline \multirow{2}{*}{ Etkileyicilik } & 1. Lise ve alt1 & 31 & 60.03 & 1861.00 & \multirow{2}{*}{1146.000} & \multirow{2}{*}{.473} \\
\hline & 2. Üniversite ve üstü & 81 & 55.15 & 4467.00 & & \\
\hline \multirow{2}{*}{ Kişilik } & 1. Lise ve alt 1 & 31 & 55.16 & 1710.00 & \multirow{2}{*}{1214.000} & \multirow{2}{*}{.783} \\
\hline & 2. Üniversite ve üstü & 81 & 57.01 & 4618.00 & & \\
\hline \multirow{2}{*}{ Motive Etme } & 1. Lise ve altı & 31 & 57.84 & 1793.00 & \multirow{2}{*}{1214.000} & \multirow{2}{*}{.784} \\
\hline & 2. Üniversite ve üstü & 81 & 55.99 & 4535.00 & & \\
\hline \multirow{2}{*}{ Etkili Konuşma Becerisi } & 1. Lise ve alt1 & 31 & 66.37 & 2057.50 & \multirow{2}{*}{949.500} & \multirow{2}{*}{.044} \\
\hline & 2. Üniversite ve üstü & 81 & 52.72 & 4270.50 & & \\
\hline \multirow{2}{*}{ Sıradışı Görünüş } & 1. Lise ve alt1 & 31 & 64.69 & 2005.50 & \multirow{2}{*}{1001.500} & \multirow{2}{*}{.095} \\
\hline & 2. Üniversite ve üstü & 81 & 53.36 & 4322.50 & & \\
\hline \multirow{2}{*}{ Risk Alma } & 1. Lise ve alt1 & 31 & 60.24 & 1867.50 & \multirow{2}{*}{1139.500} & \multirow{2}{*}{.445} \\
\hline & 2. Üniversite ve üstü & 81 & 55.07 & 4460.50 & & \\
\hline \multirow{2}{*}{ Değerlerine Sahip Çıkma } & 1. Lise ve alt1 & 31 & 60.68 & 1881.00 & \multirow{2}{*}{1126.000} & \multirow{2}{*}{.390} \\
\hline & 2. Üniversite ve üstü & 81 & 54.90 & 4447.00 & & \\
\hline \multirow{2}{*}{ Grubun Sosyal Bütünleşmesi } & 1. Lise ve alt1 & 31 & 63.71 & 1975.00 & 1032000 & 145 \\
\hline & 2. Üniversite ve üstü & 81 & 53.74 & 4353.00 & 1032.000 & .145 \\
\hline & 1. Lise ve alt1 & 31 & 60.34 & 1870.50 & 1136500 & 437 \\
\hline Grubun Gorev Çekıcılıgı & 2. Üniversite ve üstü & 81 & 55.03 & 4457.50 & & \\
\hline & 1. Lise ve alt 1 & 31 & 70.10 & 2173.00 & 834000 & 006 \\
\hline & 2. Üniversite ve üstü & 81 & 51.30 & 4155.00 & & \\
\hline Grubun Görevde & 1. Lise ve alt1 & 31 & 64.55 & 2001.00 & 006000 & 090 \\
\hline Bütünleşmesi & 2. Üniversite ve üstü & 81 & 53.42 & 4327.00 & 1000.000 & (0) \\
\hline
\end{tabular}

*P<0,05; N (112)

Sporcuların eğitim durumu değişkenine görekarizmatik liderlik ve grup sargınlığı alg1 düzeyleri arasında, anlamlı bir farklılık olup olmadığını test etmek amacıyla yapılan MannWithney $U$ testi sonucunda, etkili konuşma becerisi $(U=949.500, p<0.05)$ ve grubun sosyal çekiciliği $(\mathrm{U}=834.000, \mathrm{p}<0.05)$ alt boyutları arasında istatistiksel olarak anlamlı farklılık tespit edilirken, diğer alt boyutlar arasında istatistiksel olarak anlamlı farklılık bulunamamıştır.

Yaş değişkeni ile bağımlı değişkenler arasındaki anlamlı farklılı̆̆ın tespitine yönelik varyans analizi sonuçları tablo 3 'te sunulmuştur. 
Tablo 3. Sporcuların Karizmatik Liderlik Ve Grup Sargınlı̆̆ılglgı Düzeylerinin Yaş Değişkenine Göre Varyans Analizi Sonuçları

\begin{tabular}{|c|c|c|c|c|c|c|c|}
\hline Bağımlı Değişkenler & Yaş & $\mathbf{N}$ & Sira ort. & sd & $\chi^{2}$ & $\mathbf{p}$ & $(\mathbf{I}-\mathbf{J})$ \\
\hline \multirow{4}{*}{ Kişiselleştirilmiş İlgi } & 1. 18 yaş ve altı & 16 & 77.13 & \multirow{4}{*}{3} & \multirow{4}{*}{8.109} & \multirow{4}{*}{.044} & \multirow{4}{*}{$1-2$} \\
\hline & 2. 19-22 yaş arası & 50 & 52.53 & & & & \\
\hline & 3. 23-26 yaş arası & 24 & 50.67 & & & & \\
\hline & 4. 27 yaş ve üstü & 22 & 56.89 & & & & \\
\hline \multirow{4}{*}{ Güven } & 1. 18 yaş ve altı & 16 & 59.78 & \multirow{4}{*}{3} & \multirow{4}{*}{1.583} & \multirow{4}{*}{.663} & \\
\hline & 2. $19-22$ yaş arası & 50 & 52.24 & & & & \\
\hline & 3. $23-26$ yaş arası & 24 & 60.52 & & & & \\
\hline & 4. 27 yaş ve üstü & 22 & 59.41 & & & & \\
\hline \multirow{4}{*}{ Antipatik Algı } & 1. 18 yaş ve altı & 16 & 42.59 & \multirow{4}{*}{3} & \multirow{4}{*}{6.693} & \multirow{4}{*}{.082} & \\
\hline & 2. 19-22 yaş arası & 50 & 60.07 & & & & \\
\hline & 3. 23-26 yaş arası & 24 & 65.44 & & & & \\
\hline & 4. 27 yaş ve üstü & 22 & 48.75 & & & & \\
\hline \multirow{4}{*}{ Etkileyicilik } & 1. 18 yaş ve altı & 16 & 64.69 & \multirow{4}{*}{3} & \multirow{4}{*}{5.318} & \multirow{4}{*}{.150} & \\
\hline & 2. 19-22 yaş arası & 50 & 60.96 & & & & \\
\hline & 3. 23-26 yaş arası & 24 & 44.98 & & & & \\
\hline & 4. 27 yaş ve üstü & 22 & 52.98 & & & & \\
\hline \multirow{4}{*}{ Kişilik } & 1. 18 yaş ve altı & 16 & 61.94 & \multirow{4}{*}{3} & \multirow{4}{*}{5.928} & \multirow{4}{*}{.115} & \\
\hline & 2. 19-22 yaş arası & 50 & 59.03 & & & & \\
\hline & 3. $23-26$ yaş arası & 24 & 61.04 & & & & \\
\hline & 4. 27 yaş ve üstü & 22 & 41.84 & & & & \\
\hline \multirow{4}{*}{ Motive Etme } & 1. 18 yaş ve altı & 16 & 66.88 & \multirow{4}{*}{3} & \multirow{4}{*}{3.092} & \multirow{4}{*}{.378} & \\
\hline & 2. $19-22$ yaş arası & 50 & 58.08 & & & & \\
\hline & 3. $23-26$ yaş aras 1 & 24 & 51.04 & & & & \\
\hline & 4. 27 yaş ve üstü & 22 & 51.32 & & & & \\
\hline \multirow{4}{*}{ Etkili Konuşma Becerisi } & 1. 18 yaş ve altı & 16 & 61.97 & \multirow{4}{*}{3} & & & \\
\hline & 2. $19-22$ yaş arası & 50 & 57.52 & & 1018 & 707 & \\
\hline & 3. $23-26$ yaş aras 1 & 24 & 52.10 & & 1.018 & (19). & \\
\hline & 4. 27 yaş ve üstü & 22 & 49.73 & & & & \\
\hline & 1. 18 yaş ve altı & 16 & 65.63 & & & & \\
\hline Suradısı Görïnüs & 2. $19-22$ yaş arası & 50 & 58.30 & 3 & 2731 & 135 & \\
\hline & 3. $23-26$ yaş aras 1 & 24 & 52.88 & 3 & 2.131 & .435 & \\
\hline & 4. 27 yaş ve üstü & 22 & 49.73 & & & & \\
\hline & 1. 18 yaş ve altı & 16 & 70.34 & & & & \\
\hline Risk Alma & 2. 19-22 yaş arası & 50 & 56.27 & 3 & 4.022 & .259 & \\
\hline & 3. $23-26$ yaş arası & 24 & 53.44 & 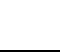 & & & \\
\hline
\end{tabular}




\begin{tabular}{|c|c|c|c|c|c|c|c|}
\hline & 4. 27 yaş ve üstü & 22 & 50.30 & & & & \\
\hline \multirow{4}{*}{ Değerlerine Sahip Çıkma } & 1. 18 yaş ve altı & 16 & 69.53 & \multirow{4}{*}{3} & \multirow{4}{*}{3.795} & \multirow{4}{*}{.284} & \\
\hline & 2. $19-22$ yaş arası & 50 & 56.11 & & & & \\
\hline & 3. $23-26$ yaş arası & 24 & 49.77 & & & & \\
\hline & 4. 27 yaş ve üstü & 22 & 55.25 & & & & \\
\hline \multirow{4}{*}{ Grubun Sosyal Bütünleşmesi } & 1. 18 yaş ve altı & 16 & 47.50 & \multirow{4}{*}{3} & \multirow{4}{*}{3.607} & \multirow{4}{*}{.307} & \\
\hline & 2. $19-22$ yaş arası & 50 & 53.34 & & & & \\
\hline & 3. $23-26$ yaş arası & 24 & 63.17 & & & & \\
\hline & 4. 27 yaş ve üstü & 22 & 62.95 & & & & \\
\hline \multirow{4}{*}{ Grubun Görev Çekiciliği } & 1. 18 yaş ve altı & 16 & 56.22 & \multirow{4}{*}{3} & \multirow{4}{*}{2.493} & \multirow{4}{*}{.477} & \\
\hline & 2. $19-22$ yaş arası & 50 & 61.49 & & & & \\
\hline & 3. $23-26$ yaş arası & 24 & 50.08 & & & & \\
\hline & 4. 27 yaş ve üstü & 22 & 52.36 & & & & \\
\hline \multirow{4}{*}{ Grubun Sosyal Çekiciliği } & 1. 18 yaş ve altı & 16 & 59.81 & \multirow{4}{*}{3} & \multirow{4}{*}{1.274} & \multirow{4}{*}{.735} & \\
\hline & 2. $19-22$ yaş arası & 50 & 57.64 & & & & \\
\hline & 3. 23-26 yaş arası & 24 & 58.17 & & & & \\
\hline & 4. 27 yaş ve üstü & 22 & 49.68 & & & & \\
\hline \multirow{4}{*}{$\begin{array}{l}\text { Grubun Görevde } \\
\text { Bütünleşmesi }\end{array}$} & 1. 18 yaş ve altı & 16 & 74.34 & \multirow{4}{*}{3} & \multirow{4}{*}{8.686} & \multirow{4}{*}{.034} & $1-2$ \\
\hline & 2. $19-22$ yaş arası & 50 & 49.55 & & & & \\
\hline & 3. $23-26$ yaş arası & 24 & 52.77 & & & & \\
\hline & 4. 27 yaş ve üstü & 22 & 63.39 & & & & \\
\hline
\end{tabular}

$* \mathrm{P}<0,05 ; * * \mathrm{P}<0,008 ; \mathrm{N}(112)$

Sporcuların yaş değişkenine göre karizmatik liderlik ve grup sargınlığı alg1 düzeyleri arasında, anlamlı bir farklılık olup olmadığını test etmek amacıyla yapılan Kruskal Wallis $\mathrm{H}$ testi sonucunda, yaş değişkeni ilekişiselleştirilmiş ilgi $\left.\chi^{2}(\mathrm{sd}=3, \mathrm{n}=112)=8.109, \mathrm{p}<0.05\right)$ ve grubun görevde bütünleşmesi $22(\mathrm{sd}=3, \mathrm{n}=112)=8.686, \mathrm{p}<0.05)$ alt boyutu arasında, istatistiksel olarak anlamlı farklılık tespit edilirken, diğer alt boyutlararasında, istatistiksel olarak anlamlı farklılık tespit edilememiştir.

Kişiselleştirilmiş ilgi alt boyutundaki anlamlı farklılı̆̆ın hangi yaş kategorileri arasındaolduğunu tespit etmek için yapılan tekrarlıMann Whitney $U$ testleri sonucunda, sadece 18 yaş ve altı sporcular ile 19-22 yaş kategorisindeki sporcular $(U=221.000, p<0.008)$ arasında istatistiksel olarak anlamlı farklılık tespit edilirken, diğer yaş kategorileriarasında istatistiksel olarak anlamlı farklılık tespit edilememiştir ( $\mathrm{p}>0.008$ ). Benzer şekilde grubun görevde bütünleşmesi alt boyutunda da 18 yaş ve altı sporcular ile 19-22 yaş kategorisindeki sporcular ( $U=225.500$, $\mathrm{p}<0.008)$ arasında istatistiksel olarak anlamlı farklılık tespit edilirken, diğer yaş kategorileri arasında istatistiksel olarak anlamlı farklılık olmadığı belirlenmiştir $(\mathrm{p}>0.008)$.

Spor yaş değişkeni ile bağımlı değişkenler arasındaki anlamlı farklılığın tespitine yönelik varyans analizi sonuçları tablo 4'te sunulmuştur. 
Tablo 4. Sporcuların Karizmatik Liderlik Ve Grup Sargınlığı Algı Düzeylerinin Spor Yaşı Değişkenine Göre Varyans Analizi Sonuçları

\begin{tabular}{|c|c|c|c|c|c|c|c|}
\hline Bağımlı Değişkenler & Spor Yaşı & $\mathbf{N}$ & Sira ort. & sd & $\chi^{2}$ & $\mathbf{p}$ & $(\mathbf{I}-\mathbf{J})$ \\
\hline \multirow{4}{*}{ Kişiselleştirilmiş İlgi } & 1. 5 yil ve alt1 & 22 & 59.80 & \multirow{4}{*}{3} & \multirow{4}{*}{1.018} & \multirow{4}{*}{.797} & \\
\hline & 2. 6-10 y1l aras1 & 47 & 53.29 & & & & \\
\hline & 3. $11-15$ y1l aras1 & 23 & 60.28 & & & & \\
\hline & 4. 16 y1l ve üstü & 20 & 56.08 & & & & \\
\hline \multirow{4}{*}{ Güven } & 1. 5 y1l ve altı & 22 & 63.57 & \multirow{4}{*}{3} & \multirow{4}{*}{2.691} & \multirow{4}{*}{.442} & \\
\hline & 2. 6-10 y1l aras1 & 47 & 53.85 & & & & \\
\hline & 3. $11-15$ y1l aras1 & 23 & 61.02 & & & & \\
\hline & 4. 16 y1l ve üstü & 20 & 49.75 & & & & \\
\hline \multirow{4}{*}{ Antipatik Algı } & 1. 5 y1l ve alt 1 & 22 & 57.20 & \multirow{4}{*}{3} & \multirow{4}{*}{3.394} & \multirow{4}{*}{.335} & \\
\hline & 2. 6-10 y1l aras 1 & 47 & 60.41 & & & & \\
\hline & 3. $11-15$ y1l aras1 & 23 & 58.02 & & & & \\
\hline & 4. 16 y1l ve üstü & 20 & 44.78 & & & & \\
\hline \multirow{4}{*}{ Etkileyicilik } & 1. 5 y1l ve altı & 22 & 61.27 & \multirow{4}{*}{3} & \multirow{4}{*}{6.363} & \multirow{4}{*}{.095} & \\
\hline & 2. 6-10 y1l arası & 47 & 62.73 & & & & \\
\hline & 3. $11-15$ y1l aras1 & 23 & 43.76 & & & & \\
\hline & 4. 16 y1l ve üstü & 20 & 51.25 & & & & \\
\hline \multirow{4}{*}{ Kişilik } & 1. 5 y1l ve altı & 22 & 59.68 & \multirow{4}{*}{3} & \multirow{4}{*}{1.706} & \multirow{4}{*}{.636} & \\
\hline & 2. 6-10 y1l arası & 47 & 59.52 & & & & \\
\hline & 3. $11-15$ y1l aras1 & 23 & 50.74 & & & & \\
\hline & 4. 16 y1l ve üstü & 20 & 52.53 & & & & \\
\hline \multirow{4}{*}{ Motive Etme } & 1. 5 y1l ve alt 1 & 22 & 58.27 & \multirow{4}{*}{3} & \multirow{4}{*}{2.164} & \multirow{4}{*}{.539} & \\
\hline & 2. 6-10 y1l aras1 & 47 & 60.55 & & & & \\
\hline & 3. $11-15$ y1l aras1 & 23 & 49.48 & & & & \\
\hline & 4. 16 y1l ve üstü & 20 & 53.10 & & & & \\
\hline \multirow{4}{*}{ Etkili Konuşma Becerisi } & 1. 5 y1l ve altı & 22 & 54.82 & \multirow{4}{*}{3} & \multirow{4}{*}{1.053} & & \\
\hline & 2. 6-10 y1l arasi & 47 & 59.88 & & & 788 & \\
\hline & 3. $11-15$ y1l aras1 & 23 & 55.30 & & & .188 & \\
\hline & 4. 16 y1l ve üstü & 20 & 51.78 & & & & \\
\hline & 1. 5 yil ve altı & 22 & 64.02 & & & & \\
\hline Suradısı Görïnüs & 2. 6-10 y1l aras1 & 47 & 62.77 & 3 & 7811 & 050 & \\
\hline & 3. $11-15$ y1l aras1 & 23 & 44.78 & 3 & 1.812 & (050 & \\
\hline & 4. 16 yil ve üstü & 20 & 46.98 & & & & \\
\hline & 1. 5 y1l ve alt 1 & 22 & 66.07 & & & & \\
\hline Risk Alma & 2. 6-10 y1l aras 1 & 47 & 56.37 & 3 & 2.924 & .404 & \\
\hline & 3. $11-15$ y1l aras1 & 23 & 51.07 & & & & \\
\hline
\end{tabular}




\begin{tabular}{|c|c|c|c|c|c|c|c|}
\hline & 4. 16 yıl ve üstü & 20 & 52.53 & & & & \\
\hline \multirow{4}{*}{ Değerlerine Sahip Çıkma } & 1. 5 y1l ve alt 1 & 22 & 71.95 & \multirow{4}{*}{3} & \multirow{4}{*}{9.551} & \multirow{4}{*}{.023} & \multirow{4}{*}{$1-3$} \\
\hline & 2. $6-10$ y1l aras1 & 47 & 53.27 & & & & \\
\hline & 3. $11-15$ y1l aras1 & 23 & 44.20 & & & & \\
\hline & 4. 16 yıl ve üstü & 20 & 61.25 & & & & \\
\hline \multirow{4}{*}{ Grubun Sosyal Bütünleşmesi } & 1. 5 y1l ve alt 1 & 22 & 58.82 & \multirow{4}{*}{3} & \multirow{4}{*}{8.319} & \multirow{4}{*}{.040} & \multirow{4}{*}{$2-4$} \\
\hline & 2. 6-10 y1l aras1 & 47 & 49.44 & & & & \\
\hline & 3. $11-15$ y1l aras 1 & 23 & 53.59 & & & & \\
\hline & 4. 16 yıl ve üstü & 20 & 73.90 & & & & \\
\hline \multirow{4}{*}{ Grubun Görev Çekiciliği } & 1. 5 y1l ve altı & 22 & 61.68 & \multirow{4}{*}{3} & \multirow{4}{*}{0.703} & \multirow{4}{*}{.873} & \\
\hline & 2. 6-10 y1l aras1 & 47 & 55.18 & & & & \\
\hline & 3. $11-15$ y1l aras1 & 23 & 55.41 & & & & \\
\hline & 4. 16 yıl ve üstü & 20 & 55.15 & & & & \\
\hline \multirow{4}{*}{ Grubun Sosyal Çekiciliği } & 1. 5 y1l ve altı & 22 & 52.80 & \multirow{4}{*}{3} & \multirow{4}{*}{2.242} & \multirow{4}{*}{.524} & \\
\hline & 2. $6-10$ y1l aras1 & 47 & 54.28 & & & & \\
\hline & 3. $11-15$ y1l aras1 & 23 & 56.33 & & & & \\
\hline & 4. 16 y1l ve üstü & 20 & 66.00 & & & & \\
\hline \multirow{4}{*}{$\begin{array}{l}\text { Grubun Görevde } \\
\text { Bütünleşmesi }\end{array}$} & 1. 5 y1l ve alt 1 & 22 & 58.91 & \multirow{4}{*}{3} & \multirow{4}{*}{13.177} & \multirow{4}{*}{.004} & \multirow{4}{*}{ 3-4 } \\
\hline & 2. $6-10$ y1l aras1 & 47 & 56.81 & & & & \\
\hline & 3. $11-15$ y1l aras1 & 23 & 38.27 & & & & \\
\hline & 4. 16 yıl ve üstü & 20 & $\mathbf{7 3 . 7 5}$ & & & & \\
\hline
\end{tabular}

$* \mathrm{P}<0,05 ; * * \mathrm{P}<0,008 ; \mathrm{N}(112)$

Sporcuların spor yaşı değişkenine göre karizmatik liderlik ve grup sargınlığı algı düzeyleri arasında, anlamlı bir farklılık olup olmadığını test etmek amacıyla yapılan Kruskal Wallis $\mathrm{H}$ testi sonucunda, spor yaşı değişkeni ile sıradış1 görünüş $\left.\chi^{2}(\mathrm{sd}=3, \mathrm{n}=112)=7.812, \mathrm{p}<0.05\right)$, değerlerine sahip ç1kma $2(\mathrm{sd}=3, \mathrm{n}=112)=9.551, \mathrm{p}<0.05)$, grubun sosyal bütünleşmesi $\chi^{2}(\mathrm{sd}=3, \mathrm{n}=112)=$ $8.319, \mathrm{p}<0.05)$ ve grubun görevde bütünleşmesi $\left.\chi^{2}(\mathrm{sd}=3, \mathrm{n}=112)=13.177, \mathrm{p}<0.05\right)$ alt boyutları arasında, istatistiksel olarak anlamlı farklılık tespit edilirken, diğer alt boyutlararasında, istatistiksel olarak anlamlı farklılık tespit edilememiştir.

Değerlerine sahip çıkma alt boyutundaki anlamlı farklılığın hangi spor yaşı aralığından kaynaklandığını tespit etmek için yapılan tekrarlı Mann Whitney U testleri sonucunda, 5 yıl ve altı tecrübeye sahip sporcular ile 11-15 y1l arası tecrübeye sahip sporcular $(\mathrm{U}=126.500, \mathrm{p}<0.008)$, arasında, grubun sosyal bütünleşmesi alt boyutunda 6-10 yıl arası tecrübeye sahip sporcular ile 16 y1l ve üstü tecrübeye sahip sporcular $(U=248.500, p<0.008)$ arasında ve grubun görevde bütünleşmesi alt boyutunda ise, 11-15 yıl arası tecrübeye sahip sporcular ile 16 yıl ve üstü tecrübeye sahip sporcular $(\mathrm{U}=86.000, \mathrm{p}<0.008)$, arasında, istatistiksel olarak anlamlı farklilık tespit edilirken, diğer spor yaşı kategorileri arasında istatistiksel olarak anlamlı farklılık olmadığ saptanmıştır $(p>0.008)$. Sıradış1 görünüş alt boyutunda ise, varyans analizi sonucunda anlamlı farklılık tespit edilsede, yapılan tekrarlı ikili karşılaştırmalardan kaynaklanabilecek tip I ve tip II hatanın önüne geçmek için elde edilen anlamlı farklılığa ilişkin sonuçlar, belirlenen yeni anlamlılık seviyesinin $(\mathrm{p}=0,008)$ üzerinde olduğu için anlamlı farkl1lık yoktur şeklinde değerlendirilmiştir. 
Mevcut antrenörle çalışma süresi değişkeni ile bağımlı değişkenler arasındaki anlamlı farklılığın tespitine yönelik t-testi sonuçları tablo 5'te sunulmuştur.

Tablo 5. Sporcuların Karizmatik Liderlik ve Grup Sargınlığı Algı Düzeylerininmevcut Antrenörü İle Çalışma Süresi Değişkenine Göre Karşılaştırılması

\begin{tabular}{|c|c|c|c|c|c|c|}
\hline Bağımlı Değişkenler & MAÇS & $\mathbf{N}$ & Sira ort. & Sira top. & $\mathbf{U}$ & $\mathbf{p}$ \\
\hline \multirow{2}{*}{ Kişiselleştirilmiş İlgi } & 1. 2 y1l ve alt & 76 & 49.64 & 3773.00 & \multirow{2}{*}{847.000} & \multirow{2}{*}{.001} \\
\hline & 2. 3 yıl ve üstü & 36 & 70.97 & 2555.00 & & \\
\hline \multirow{2}{*}{ Güven } & 1. 2 y1l ve altı & 76 & 59.99 & 4559.00 & \multirow{2}{*}{1103.000} & \multirow{2}{*}{.097} \\
\hline & 2. 3 yıl ve üstü & 36 & 49.14 & 1769.00 & & \\
\hline \multirow{2}{*}{ Antipatik Algı } & 1. 2 y1l ve alt1 & 76 & 62.23 & 54729.50 & \multirow{2}{*}{932.500} & \multirow{2}{*}{.006} \\
\hline & 2. 3 yıl ve üstü & 36 & 44.40 & 1598.50 & & \\
\hline \multirow{2}{*}{ Etkileyicilik } & 1. 2 y1l ve altı & 76 & 54.84 & 4168.00 & \multirow{2}{*}{1242.000} & \multirow{2}{*}{.429} \\
\hline & 2. 3 yıl ve üstü & 36 & 60.00 & 2160.00 & & \\
\hline \multirow{2}{*}{ Kişilik } & 1. 2 y1l ve alt1 & 76 & 56.71 & 4310.00 & \multirow{2}{*}{1352.000} & \multirow{2}{*}{.919} \\
\hline & 2. 3 yıl ve üstü & 36 & 56.06 & 2018.00 & & \\
\hline \multirow{2}{*}{ Motive Etme } & 1. 2 y1l ve altı & 76 & 54.49 & 4141.50 & \multirow{2}{*}{1215.500} & \multirow{2}{*}{.334} \\
\hline & 2. 3 yıl ve üstü & 36 & 60.74 & 2186.50 & & \\
\hline \multirow{2}{*}{ Etkili Konuşma Becerisi } & 1. 2 y1l ve alt1 & 76 & 56.36 & 4283.50 & \multirow{2}{*}{1357.500} & \multirow{2}{*}{.947} \\
\hline & 2. 3 yıl ve üstü & 36 & 56.79 & 2044.50 & & \\
\hline \multirow{2}{*}{ Sıradışı Görünüş } & 1. 2 y1l ve alt1 & 76 & 57.59 & 4376.50 & \multirow{2}{*}{1285.500} & \multirow{2}{*}{.603} \\
\hline & 2. 3 yıl ve üstü & 36 & 54.21 & 1951.50 & & \\
\hline \multirow{2}{*}{ Risk Alma } & 1. 2 y1l ve altı & 76 & 59.13 & 4494.00 & \multirow{2}{*}{1168.000} & \multirow{2}{*}{.207} \\
\hline & 2. 3 yıl ve üstü & 36 & 50.94 & 1834.00 & & \\
\hline \multirow{2}{*}{ Değerlerine Sahip Çıkma } & 1. 2 y1l ve altı & 76 & 56.20 & 4271.50 & \multirow{2}{*}{1345.500} & \multirow{2}{*}{.886} \\
\hline & 2. 3 yıl ve üstü & 36 & 57.13 & 2056.50 & & \\
\hline \multirow{2}{*}{ Grubun Sosyal Bütünleşmesi } & 1. 2 y1l ve altı & 76 & 55.61 & 4226.50 & 1300500 & 673 \\
\hline & 2. 3 y1l ve üstü & 36 & 58.38 & 2101.50 & & $.0 / 3$ \\
\hline & 1. 2 y1l ve alt1 & 76 & 55.03 & 4182.00 & 1256000 & 484 \\
\hline Grubun Görev Çekiciliği & 2. 3 yıl ve üstü & 36 & 59.61 & 2146.00 & 1256.000 & .484 \\
\hline & 1. 2 y1l ve altı & 76 & 55.59 & 4224.50 & & 663 \\
\hline Grubun Sosyal Çekiciliği & 2. 3 yıl ve üstü & 36 & 58.43 & 2103.50 & 1298.500 & .663 \\
\hline Grubun Görevde & 1. 2 y1l ve altı & 76 & 54.12 & 4113.00 & & \\
\hline Bütünleşmesi & 2. 3 yıl ve üstü & 36 & 61.53 & 2215.00 & $118 \% .000$ & .252 \\
\hline
\end{tabular}

*P<0,05; N (112) (MAÇS=Mevcut antrenörü ile çalışma süresi)

Sporcularınmevcut antrenörle çalışma süresi değişkenine göre karizmatik liderlik ve grup sargınlığı algı düzeyleri arasında, anlamlı bir farklılık olup olmadığını test etmek amacıyla yapılan Mann-Withney $U$ testi sonucunda, kişiselleştirilmiş ilgi $(U=847.000, p<0.05)$ ve antipatik alg1 $(\mathrm{U}=932.500, \mathrm{p}<0.05)$ alt boyutları arasinda istatistiksel olarak anlamlı farklılık tespit edilirken, diğer alt boyutlar arasında istatistiksel olarak anlamlı farklılık saptanamamıştır. 


\section{Tartışma}

Tablo 1'i incelediğimizde, katılımcıların 1. Hentbol liginde mücadele eden erkek sporculardan oluştuğu görülmektedir. Sporcuların eğitim durumu değişkenine ilişkin sonuçlara bakıldığında \% 27,7'sinin lise ve altı öğretim programlarından mezun olduğu, \% 72,3'ünün ise üniversite ve üstü öğretim programlarından mezun olduğunu saptanmıştır. Yaş değişkenine göre dağılım, sporcuların \% 14,3 ile 18 yaş ve altı, \% 44,6 ile 19-22 yaş, \% 21,4 ile 23-26 yaş ve \% 19,6 ile 27 yaş ve üstü şeklinde gerçekleşmiştir. Spor yaşı değişkenine göre ise, sporcuların \% 19,6'sının 5 yıl ve alt1, \% 42,0'inın 6-10 y1l aras1 \% 20,5'inin 11-15 yıl ve \% 17,9'unun 16 yıl ve üstü bir spor tecrübesine sahip olduğu görülmektedir. Sporcuların \% 67,9'u mevcut antrenörü ile 2 y1l ve altı süre çalışmışken, \% 32,1'i ise mevcut antrenörü ile 3 yıl veya daha uzun süre çalışmıştır.

Sporcuların eğitim durumu değişkenine göre karizmatik liderlik ve grup sargınlığ düzeyleri arasında, elde edilen sonuçlar incelendiğinde, etkili konuşma becerisi ( $U=949.500$, $\mathrm{p}<0.05)$ ve grubun sosyal çekiciliği $(\mathrm{U}=834.000, \mathrm{p}<0.05)$ alt boyutları arasında istatistiksel olarak anlamlı farklılık tespit edilirken, diğer alt boyutlar arasında anlamlı bir bulgu tespit edilememiştir. Çelik, 2011 yılında basketbol sporcuları üzerine yaptığı çalışmada eğitim düzeyi değişkenine göre kişiselleştirilmiş ilgi alt boyutunda istatistiksel olarak anlamlı bir farkl1lık gözlemlemiştir. Toros, 2009 yılında algılanan antrenörlük davranışı ile takım sargınlığı (bütünlüğü) arasındaki ilişkiyi inceleyen çalışmada sezon öncesi, görev çekiciliği, sosyal çekicilik, görev bütünlüğü ile eğitim öğretim, sezon ortasında, görev çekiciliği ile eğitim öğretim, sezon sonunda ise sosyal çekicilik ile eğitim-öğretim arasında bir ilişki bulunduğu ifade edilmektedir.

Sporcuların yaş değişkenine göre karizmatik liderlik ve grup sargınlığı algı düzeyleri arasında, anlamlı bir farklılık olup olmadığını test etmek amacıyla çıkan sonuçlarda, yaş değişkeni ile kişiselleştirilmiş ilgi $\left.\chi^{2}(\mathrm{sd}=3, \mathrm{n}=112)=8.109, \mathrm{p}<0.05\right)$ ve grubun görevde bütünleşmesi $\chi^{2}$ $(\mathrm{sd}=3, \mathrm{n}=112)=8.686, \mathrm{p}<0.05)$ alt boyutu arasında, istatistiksel olarak anlamlı farklilık tespit edilirken, diğer alt boyutlar arasında, istatistiksel olarak anlamlı farklılık tespit edilememiştir. Kişiselleştirilmiş ilgi alt boyutunda sadece 18 yaş ve altı sporcular ile 19-22 yaş kategorisindeki sporcular $(\mathrm{U}=221.000, \mathrm{p}<0.008)$ arasında istatistiksel olarak anlamlı farklılık tespit edilmiştir $(\mathrm{p}>0.008)$. Belirtilen yaş aralığında olan sporcular antrenörlerinin onlara karşı daha ilgili olduğunu düşünebilmektedir. Küçük yaş grubunun ihtiyaçlarının daha fazla olduğu gözönüne alındığında antrenörlerin bu yaş kitlesiyle daha fazla ilgilenmeleri olası bir durumdur. Yapılan çalışmalarda da bu sonuçları destekleyen bulgular elde edişmiştir. Basketbolcular üzerinde yapılan çalışmada, yaş değişkenine göre oluşturulan gruplar arasında, güven, değer için risk alma, etkileyicilik ve kişiselleştirilmiş ilgi alt boyutlarına ilişkin puanlarda istatistiksel olarak anlamlı bir farklılığın olduğu görülmüştür. Testler sonucunda 18 yaş ve altındaki sporcular diğer yaş grubundaki sporculara göre antrenörlerine daha fazla güvenmektedir. Çelik'in (2011) çalışmasında kişiselleştirilmiş ilgi değişkeni ile grubun görevde bütünleşmesi arasındaki olumlu ilişki, güven değişkeninin aracılık etkisi ile sağlanabildiği görülmüştür. Çalışmamızdaki bulgular Çelik (2011), Arslantaş ve Dursun'un (2008) çalışmalarından elde edilenler bulgular ile benzerlik göstermektedir. Oyuncularının ihtiyaçlarına karşı duyarlı olan antrenör, onların güvenlerini kazanarak takımının sosyal ve görev bütünlüğünü sağlayabilir. Bu yaş grubundaki sporcular, antrenörlerinin kendi ihtiyaçlarına duyarlı olduğunu düşünmekte ve antrenörleri daha etkileyici buldukları ortaya çıkmıştır (Çelik, 2011). Benzer şekilde grubun görevde bütünleşmesi alt boyutunda da 18 yaş ve altı sporcular ile 19-22 yaş kategorisindeki sporcular ( $U=225.500$, $\mathrm{p}<0.008)$ arasında istatistiksel olarak anlamlı farklılık tespit edilirken, diğer yaş kategorileri arasında istatistiksel olarak anlamlı farklılık olmadığı belirlenmiştir ( $>0.008)$.

Sporcuların spor yaşı değişkenine göre karizmatik liderlik ve grup sargınlığı algı düzeyleri arasında, ortaya çıkan veriler incelendiğinde spor yaşı değişkeni ile değerlerine sahip çıkma $\chi^{2}$ $(\mathrm{sd}=3, \mathrm{n}=112)=9.551, \mathrm{p}<0.05)$, grubun sosyal bütünleşmesi $\chi 2(\mathrm{sd}=3, \mathrm{n}=112)=8.319, \mathrm{p}<0.05)$ ve grubun görevde bütünleşmesi $\left.\chi^{2}(\mathrm{sd}=3, \mathrm{n}=112)=13.177, \mathrm{p}<0.05\right)$ alt boyutları arasında, 
istatistiksel olarak anlamlı farklılık tespit edilirken, diğer alt boyutlar arasında, istatistiksel olarak anlamlı farklılık tespit edilememiştir. Değerlerine sahip çıkma alt boyutunda 5 y1l ve altı tecrübeye sahip sporcular ile 11-15 y1l aras1 tecrübeye sahip sporcular $(\mathrm{U}=126.500, \mathrm{p}<0.008)$, arasinda, grubun sosyal bütünleşmesi alt boyutunda 6-10 yıl arası tecrübeye sahip sporcular ile 16 y1l ve üstü tecrübeye sahip sporcular $(\mathrm{U}=248.500, \mathrm{p}<0.008)$ arasında ve grubun görevde bütünleşmesi alt boyutunda ise, 11-15 y1l arası tecrübeye sahip sporcular ile 16 y1l ve üstü tecrübeye sahip sporcular $(\mathrm{U}=86.000, \mathrm{p}<0.008)$, arasında, istatistiksel olarak anlamlı farklılık tespit edilmiştir $(\mathrm{p}>0.008)$.

Sporcuların mevcut antrenörle çalışma süresi değişkeni incelendiğinde kişiselleştirilmiş ilgi $(\mathrm{U}=847.000, \mathrm{p}<0.05)$ ve antipatik alg1 $(\mathrm{U}=932.500, \mathrm{p}<0.05)$ alt boyutlar1 arasinda istatistiksel olarak anlamlı farklılık tespit edilirken, diğer alt boyutlar arasında istatistiksel olarak anlamlı farklılık saptanamamıştır. Çelik (2011), araştırma bulgularına göre antrenör ile çalışma süresi değişkenine göre oluşturulan gruplar arasında, karizmatik liderlik ölçeğinin alt boyutlarından güven, deger için risk alma, etkileyicilik ve kişiselleştirilmiş ilgiye ilişkin puanlarda anlamlı bir farklılığın olduğu görülmüsstür. Uzun süre aynı antrenör ile çalışmak, sporcuların antrenörleri ile ilgili karizma algısının oluşmasında böylesi bir rol oynamış olabilir. Uzun süredir birlikte olan takımlardaki sporcuların takımın başarısına karşı daha fazla istek duymaları ve daha yüksek düzeyde sargınlığına sahip olmaları olası bir durum olarak karşımıza çıkabilir (Carron,1982).

\section{Sonuç}

İnsanların bir amaç ve hedef etrafında toplandığı, sportif etkinlik ve spor hizmeti beklentilerini önemli ölçüde karşıladığı örgütler olarak spor kulüpleri (Demirel ve diğ, 2007: 77) varlıklarını sürdürebilmek, performanslarını artırabilmek için örgütün yapısına hakim, geniş bir vizyona sahip ve örgüt üyelerini etkileyebilme yeteneğine sahip liderlere ihtiyaç duymaktadırlar. $\mathrm{Bu}$ bağlamda örgütün yapısını geliştirmek, örgütün performansını, etkinliğini, verimliliğini motivasyon ve tatmin düzeyini artırarak örgütü başarıya taşımak için kilit öneme sahip kişinin lider olduğu anlaşılmaktadır (Şahin, 2009: 98).

Bir spor kulübünün etkili olma ve yüksek kaliteli sonuçlar yaratma kabiliyeti kişilerarası dinamikler ve süreçlerle açıkça ilişkili olduğu için, takım antrenörünün rolü, tüm kulüp faaliyetlerinden ve sonuçlarından resmi olarak sorumlu olduğu için özellikle önemlidir (Myrtveit, 2016:5). Özellikle hentbol gibi takım sporlarında görev yapan antrenörlerin, sporcuların performanslarını, motivasyonlarını ve iş doyumlarını arttıracak, örgütsel hedeflerin gerçekleştirilmesini sağlayacak ve takım içerisinde bir "bütünlük" oluşturacak liderlik davranışları ortaya koymaları en önemli faktördür. Farklı alanlarda görev yapan ve izleyicileri tarafından karizmatik olarak algılanan liderlerin, örgütlerde performansın artmasında, bütünlüğün oluşmasında, başarılı bir grafik çizilmesinde son derece başarılı oldukları takip edilmektedir. Karizmatik liderler, kendi inanç, değer ve idealleri ile ilgili olarak güven, kararlık ve güçlü bir inanış sergilerler. Karizmatik liderlerin bu davranışlarının ve kendileri hakkındaki olumlu kanının oluşması, grup üyeleri arasındaki bütünlügün oluşmasında da önemli rol oynamaktadır. Bu nedenle hentbol takımlarında görev yapan antrenörlerin sergiledikleri davranışların sporcular tarafından karizmatik olarak algılanmasının, takımın amaçlarının gerçekleştirilmesinde ve bütünlügünün (sargınlığın) oluşturulmasında önemli rol oynayabileceği görülmektedir (Çelik, 2015: 105-117).

\section{Kaynakça}

Arslantaş, C.C. \& Dursun, M. (2008). Etik Liderlik Davranışının Yöneticiye Duyulan Güven Ve Psikolojik Güçlendirme Üzerindeki Etkisine Etkileşim Adaletinin Dolaylı Rolü, Anadolu Üniversitesi Sosyal Bilimler Dergisi, 8 (1), 111-128.

Carron, A. V., Bray, S.R. \& Eys, M.A. (2002). Team cohesion and team success in sport, Journal of Sports Sciences, 20:2, 119-126. 
Carron, A.V., W.N. Widmeyer. \& L.R. Brawley. (1985). The development of an instrument to assess cohesion in sport teams: the group environment questionnaire. Journal Of Sport Psychology, 7.244-266.

Chaudhry, A. Q. \& Javed, H. (2012). Impact Of Transactional And Laissez Faire Leadership Style On Motivation, International Journal Of Business And Social Science, 3 (7), 15.

Çelik, V.O. ( 2011). Basketbol Oyuncularının Görüslerine Göre Antrenörlerinin Karizmatik Liderlik Özelliklerinin Takım Bütünlüğüne Etkisi, Doktora Tezi. Anadolu Üniversitesi Sağlık Bilimleri Enstitüsü.

Çelik, V.O. ( 2015). Spor Alanında Karizmatik Liderlerin Grup Bütünlüğü Üzerindeki Etkileri, Akademik Sosyal Araştırmalar Dergisi, 3 (11) s:104-122.

Deliveli, Ö. (2010). Yönetimde Yeni Lider Bağlamında Lider Yöneticilik, Yüksek Lisans Tezi. Süleyman Demirel Üniversitesi.

Demirel, M., Karahan, B.G. \& Ünlü, H. (2007). Farklı Üniversitelerdeki Spor Taraftarların Takımları İle Özdeşleşme Düzeyleri. Niğde Üniversitesi Beden Eğitimi Ve Spor Bilimleri Dergisi, 1 (2), 78-86.

Ertan-Kantos, Z. (2011). “Örgüt Metaforlarında Liderlik: Kavramsal Bir Çözümleme”. Eğitim Bilimleri Araştırmaları Dergisi, 1(1): 141

Güney, S. (2014). Davranış Bilimleri. 8. Baskı. Nobel Yayıncılık.

House R.J., Spangler W.D. \& Woycke J. (1990). Personality and charisma inthe US presidency: a psychological theory of leadership effective-ness. Acad Manage Proc.

House, R..J. \& Howell, J.M. (1992). Personality And Charısmatıc Leadershıp. The Leadership Quarterly, 3 (2),S. 81-108

Hoy, W. K. \& Miksel, C. G. (2010). Educational administration theory, Resarchand Practice, Turan, S. (Çev.), Nobel Yayın Dağıtım.

Katzenbach, J. \& Smith D.(1993). The discipline of teams. Harvard BusRev.

Koçel, T. (1999). İşletme Yöneticiliŭi Yönetim ve Organizasyon Organizasyonlarda

Davranış Klasik-Modern-Çağdaş Yaklaşımlar. Beta Basım Yayım Dağıtım A.Ş, İstanbul

Mudrack, P.E. (1989). Definıng group cohesıveness:a legacy of confusion?. Small Group Behavior, Vol 20. No 1. s: 37-49.

Myrtveit, R.B. (2016). The Relationship between Team Leadership and Team Performance in Management Teams. Master Thesis. Department of Psychology, Unıversity Of Oslo.

Öcel, H. \& Aydın, O. (2006). Grup Sargınlığı Ölçeği: Geçerlik ve Güvenirlik Çalışması, Türk Psikologlar Derneği, 9(18), 19-32.

Sayl1, H.\& Baytok, A. (2014). Örgütlerde Liderlik Teori Uygulama ve Yeni Perspektifler. 1. Bask1, Nobel Yayincilik.

Şahin, B. (2009). Örgütsel Gelişmenin Sağlanmasında Dönüşümcü Liderlerin Rolü. Dokuz Eylül Üniversitesi Sosyal Bilimler Dergisi, 11 (3), s. 97-118.

Yukl, G. (2018). Örgütlerde Liderlik. Çetin, Ş. \& Baltacı, R. (Çv). 8. Baskı. Nobel Yayıncılık.

Wang, E., Chou, H.W. \& Jiang, J. (2005). The impacts of charismatic leadership style on team cohesivenessand overall performance during ERP implementation, International Journal of Project Management, 23, 173-180. 
Zaccaro, S. J., Rittman, A. L. \& Marks, M. A. (2002). Team leadership. The Leadership Quarterly, 12(4), 451- 483. 